\title{
FAKTOR-FAKTOR PEMBENTUK KESADARAN BERAGAMA ANAK JALANAN
}

\author{
Hasyim Hasanah \\ Universitas Islam Negeri (UIN) Walisongo Semarang \\ e-mail: hasyimhasanah_82@yahoo.co.id \\ Abstrak
}

Kesadaran beragama merupakan salah satu unsur penting dalam kehidupan seseorang. Kesadaran beragama anak jalanan merupakan konseptualisasi watak keberagamaan yang dibentuk individu menjadi identitas personalnya. Kesadaran beragama yang berkembang saat ini dapat dipengaruhi banyak faktor, baik bersifat internal maupun eksternal. Anak jalanan dapat mengembangkan kesadaran beragama yang positif jika mampu memunculkan motivasi dan mendapat dukungan. Motivasi spiritual adalah salah satu jenis motivasi yang memiliki kontribusi membangun kesadaran beragama, hal sama diberikan oleh dukungan sosial. Penelitian ini bertujuan untuk melihat kontribusi faktor internal dan ekstemal dalam membentuk kesadaran beragama, yaitu aspek motivasional dan dukungan sosial. Aspek motivasional yang biasanya diarahkan pada tema keberagamaan adalah motivasi spiritual, seseorang dengan motivasi spiritual tinggi biasanya cenderung memiliki kesadaran menghadirkan nilai-nilai ajaran agama dalam kehidupan sehari-hari. Aspek lain adalah aspek yang bersifat ekstemal, biasanya berupa dukungan. Dukungan adalah bentuk perhatian yang diberikan pada seseorang sehingga dirinya merasa diterima lingkungannya. Seseorang dengan dukungan sosial tinggi tentu diyakini juga mampu memunculkan semangat menghadirkan tata nilai sosial yang diyakini benar, salah satunya agama.

Kata Kunci: kesadaran beragama; anak jalanan

\section{A. Pendahuluan}

Anak jalanan merupakan salah satu komunitas anak penyandang masalah sosial. Keberadaan anak jalanan sering membuat risau orang yang melihatnya. Anak jalanan identik dengan anak yang hidup di jalan, kotor, jorok, dan berkelakuan seenaknya. Anak jalanan secara umum merupakan fenomena dengan banyak problem. Saituti ${ }^{1}$ menyebutkan bahwa anak

'Saituti, "Problematika Anak Jalanan Ibu Kota: Faktor-faktor Penyebabnya", Jurnal Psikososiologi, 4, 2, 2001, 315-334. 
jalanan merupakan salah satu problem sosial ekonomi yang sampai saat ini belum dapat ditangani secara menyeluruh. Studi tentang anak jalanan hanya terbatas pada karakter sosial, ekonomi, pembinaan rumah singgah, dan kekerasan yang dialami anak jalanan. ${ }^{2}$ Studi-studi yang senantiasa berkembang hanya menyentuh pada aspek sosial dan ekonomi saja, belum banyak studi yang menekankan pada aspek psikologis yang dialami anak jalanan. Padahal studi komprehensip mengenai fenomena anak jalanan penting dilakukan, sehingga permasalahan anak jalanan dapat ditangani secara menyeluruh dan sistematis.

Tingginya pertumbuhan anak jalanan hal menarik untuk selalu dikaji. Anak jalanan sesuai dengan amanat Undang-Undang Dasar (UUD) 1945 harus dientaskan, namun realitasnya justru pertumbuhan anak jalanan yang semakin berkembang pesat tidaklah diimbangi dan dipecahkan sesuai dengan amanat UUD 1945. Di Jawa Tengah jumlah anak jalanan pada tahun 2009 tercatat sebanyak 13.025 jiwa, dan menempati peringkat keempat di Indonesia. ${ }^{3}$ Tingginya pertumbuhan anak jalanan di Jawa Tengah menyumbangkan 9\% rata-rata peningkatan jumlah anak jalanan di Indonesia yang tiap tahunnya terus mengalami peningkatan hingga $17.6 \%$. Di Semarang, berdasarkan hasil penelitian LPPM USM menyebutkan bahwa anak jalanan ada karena mereka tidak dapat memenuhi kebutuhan sosial, sehingga menjadikannya turun dan hidup di jalanan, sebanyak $83.3 \%$ kemiskinan orang tua, 1.96 orang tua menelantarkan, $0.98 \%$ problem keretakan rumah tangga, dan $13.7 \%$ keinginan sendiri karena sering dipukul orang tua dan ingin bebas. ${ }^{4}$ Problem anak jalanan menjadi masalah krusial yang membutuhkan penanganan secara serius, dan multidimensi.

\footnotetext{
${ }^{2}$ Yunda Pramuchtia, \& Nurmala K.P, “Konsep diri anakL Kasus Anaka Jalanan di Kota Bogor Provinsi Jawa Barat", Jurnal Transdisiplin Sosiologi, Komunikasi, dan Ekologi Manusia, 04, 02, 2010, h. 256; Dianah, A, "Dukungan Sosial dan Konsep Diri Pekerja Anak", Skripsi, Institut Pertanian Bogor, 2011, h. 66.

${ }^{3}$ Ginarsih Hutami, and Hartanto, Fitri and Hendrianingtyas, Meita, 2014, "Hubungan Perilaku Berisiko dengan Infeksi HIV AIDS pada Anak Jalanan di Semarang". Under Graduate Thesis, Faculty of Medicine Diponegoro University, dalam laman http://eprint. undip.ac.id/44649/2/Gunarsih_hutami_22010110130169_bab1KTI.pdf.html, diakses 11 Januari 2015; Setiawan, Eka, 2014, Hadapi Anak Jalanan Pemerintah Harus Tegas", dalam http://sindonews.com, Anak jalanan.dok.Istimewabenradit.wordpress.com, diakses 11 Januari 2015.

${ }^{4}$ LPPM USM, “Studi Karakteristik Anak Jalanan dalam Upaya Penyusuan Program dan Penanggulangannya: Kajian Empirik di Kota Semarang”, Riptek, (Universitas Semarang, 2008), h. 33 .
} 
Permasalahan anak jalanan dalam perspektif sosial budaya termasuk dalam kategori perilaku menyimpang dan abnormal karena kelompok ini memiliki nilai-nilai, norma, pranata berbeda dengan komunitas lain dengan ciri cenderung tertutup, seenaknya, dan penuh curiga. Pada perspektif psikologi, penanganan anak jalanan lebih diarahkan pada tema-tema efektivitas dan efisiensi dari aspek kepribadian. Salah satu karakteristiknya cenderung lebih tempramen, emosional, dalam tipe kepribadian lemah. Salah satu problem psikologis yang dihadapi anak jalanan adalah kesadaran (awareness).

Kesadaran merupakan tema penting dalam proses pendewasaan. ${ }^{5}$ Kesadaran adalah kondisi tau, mau, dan mengerti dengan dirinya sendiri. ${ }^{6}$ Pengertian ini dipahami sebagai kondisi mengenal diri sendiri, relaksasi diri, mawas diri, dan penemuan jati diri. Kesadaran merupakan pemahaman secara utuh mengenai jati diri yang memberikan ruang seluas-luasnya untuk bertindak dan berperilaku sejalan dengan kemampuan dan batas-batasan yang melekat dalam diri seseorang.7 Salah satu bentuk kesadaran adalah dalam hal beragama. Kesadaran beragama berarti suatu kondisi mengerti, memahami, menghayati, dan melaksanakan seluruh ajaran agama secara benar dan konsisten. ${ }^{8}$ Kesadaran beragama merupakan proses akumulasi seluruh pengalaman hidup yang dikenali sebagai refleksi dari falsafah dan pandangan hidup, sehingga menghadirkan sistem nilai positif. Nashori (2000) menyebutkan bahwa kondisi sadar lahir sebagai proses pendewasaan hasil perkembangan watak keberagamaan, dan dilanjutkan sebagai perjalanan spiritual. ${ }^{9}$

Kesadaran beragama dapat diukur dari aspek sistem nilai, cara pandang positif, serta konsistensi perilaku atas ajaran agamanya. ${ }^{10}$ Seseorang

5Gordon W Allport,. Pattern and Growth in Personality, (London: Holt Rinehart \& Winston, 1991), h. 119.

${ }^{6}$ Dahlan, dkk., Kamus Ilmiah Populer, (Surabaya: Arkola, tt), h. 264.

${ }^{7}$ Hasyim Hasanah,, Pengaruh Kesadaran dan Kematangan Beragama Terhadap Komitmen Organisasi Karyawan (Studi Kasus di RSUD Tugurejo Semarang), Tesis (tidak dipublikasikan), (IAIN Walisongo Semarang, 2008), h. 37.

8Jalaluddin, Psikologi Agama: Memahami Perilaku Keagamaan dengan Mengaplikasikan prinsip-prinsip Psikologi, (Jakarta: Rajawali Press, 2007), h. 122.

${ }^{9}$ Fuad, Nashori, Kompetensi Interpersonal ditinjau dari Kematangan Beragama, dan Jenis Kelamin, Tesis, (tidak dipublikasikan), (UGM Yogyakarta, 2000), h.18

${ }^{10}$ Watson, D, Effect, Personality, and Social Activity, Journal of Personality and Social Psychology, 63, 2, (London: Rougtagul, 1992), h. 1015. 
dikatakan memiliki kesadaran beragama yang tinggi apabila dalam kehidupannya menghadirkan sistem nilai yang positif. Sistem nilai meliputi kemampuan memahami dan menghayati ajaran agama, memiliki kemampuan merefleksikan hati nurani. Iqbal seperti yang dikutip Amin, dkk., menyebutkan bahwa sistem nilai diyakini sebagai visualisasi struktur kejiwaan. Lebih lanjut dijelaskan bahwa struktur kejiwaan ini menjadi dasar seseorang menghadirkan akhlak yang terpuji. ${ }^{11}$ Pandangan sama disampaikan oleh Gea yang menyebutkan bahwa sistem nilai positif memungkinkan seseorang berperilaku sesuai dengan tata aturan norma ajaran agama. Sistem nilai positif mengarahkan pada unsur ruhaniah terdiri dari refleksi hati nurani, harga diri, keimanan dan ketakwaan.12

Aspek kedua dari kesadaran beragama adalah cara pandang positif. Seseorang dikatakan memiliki cara pandang positif apabila mampu memandang dirinya sebagai bagian dari komponen masyarakat, dan menjalin relasi positif dengan orang lain ( $h a b l$ min al-nās). Cara pandang positif juga merupakan bentuk kecerdasan. Artinya orang dengan cara pandang positif, kehidupannya lebih berkualitas, memiliki landasan diri yang kokoh sebagai bentuk dari memaksimalkan kecerdasan yang dimiliki.

Aspek ketiga dari kesadaran beragama adalah konsistensi perilaku. Soedarsono menyebutkan bahwa konsistensi perilaku sebagai aspek dar kesadaran beragama menyangkut aspek praktis dari sikap dan perilaku yang ditampilkan sehari-hari.13 Terdapat dua unsur konsistensi perilaku yaitu keramahan/kesantunan, dan ketangguhan. Soedarsono menyebut-nya dengan keuletan, kreativitas, dan kelincahan. Seseorang dikatakan memiliki konsistensi perilaku apabila tindakan dan perilakunya mencerminkan kesantunan, ketulusan, dan kesalehan sosial. Perilaku lainnya mengarah pada upaya mengembangkan potensi yang dimiliki, memiliki kreativitas tinggi, dan pantang menyerah (tangguh). ${ }^{14}$

Kesadaran beragama pada diri individu memiliki kadar yang berbeda. Ada individu yang memiliki kadar kesadaran beragama tinggi, dan ada pula

11Munirul Amin, dkk, Psikologi Kesempurnaan, (Yogyakarta: Ar Ruz., 2005), h. 34.

${ }^{12}$ Antonius Atosakhi Gea, Relasasi dengan Diri Sendiri, (Jakarta: Elexmedia Komputindo, 2002), h. 71. h. 102.

${ }^{13}$ Soemarno Soedarsono, Penyemaian Jati Diri, (Jakarta: Elexmedia Komputindo, 2000),

${ }^{14}$ Ibid., h. 104. 
yang memiliki kadar yang rendah. Kadar kesadaran beragama yang rendah dialami oleh para anak jalanan. Berdasarkan hasil penelitian yang dilakukan oleh Pramuchtia dan Pandjaitan (2010) di Bogor, sekitar 36\% anak jalanan sering berkelahi, 76,66\% merasa kecewa dengan kehidupannya, sehingga mereka tidak mampu mengelola emosi dan cenderung agresif, $36 \%$ merasa menyerah dan melakukan perbuatan negatif, dan 46,6\% merasa memiliki hal yang tidak pantas untuk dibanggakan. ${ }^{15}$ Problem kesadaran beragama lain berupa ketidak-mampuan mengambil risiko dan keputusan. Problem ini masuk dalam aspek cara pandang negatif. Nurmawati (2010) menyebutkan bahwa sebagian besar anak jalanan merasa tidak berdaya, tidak berguna, dan tidak memiliki kemampuan apa-apa. Cara pandang negatif pada diri seseorang akan menyebabkan kesadaran beragama rendah.

Hasil penelitian yang dilakukan Hasanah (2013) menyebutkan bahwa kesadaran beragama yang rendah, umumnya dimiliki oleh mereka dalam situasi sosial yang tidak menguntungkan, seperti kemiskinan, tidak memiliki pekerjaan, menggelandang, mendapatkan tindak kererasan, hidup di jalanan, dan hidup dengan ketidakadilan. ${ }^{16}$ Lebih lanjut dijelaskan bahwa kemiskinan dan anak jalanan memiliki kontribusi besar terhadap problem kesadaran beragama. Perilaku anak jalanan yang ditunjukkan dari kurangnya kesadaran beragama dapat dilihat dari perilaku liar, sangat membahayakan, kurang santun beribadah, memiliki ketidaksesuaian antara lisan, ucapan, dan perilaku. Anak jalanan sering berbicara kotor, jorok, hidup seenaknya, dan melalaikan perintah ajaran agamanya. ${ }^{17}$ Ibadah sering ditinggalkan, sikap dan perilaku mengarah pada kemungkaran seperti narkoba, minum-minuman keras, hingga mabuk-mabukan secara berkelompok.18

Studi anak jalanan yang dilakukan di Surabaya menunjukkan bahwa anak jalanan sering melakukan perilaku membahayakan bagi dirinya sendiri

15Pramuchtia dan Pandjaitan, ibid, h. 22.

16Hasyim Hasanah, "Peran Strategis Aktivis Nurul Jannah al Firdaus dalam Membentuk Kesadaran Beragama Perempuan Miskin Kota," Inferensi Jurnal Penelitian Sosial Keagamaan STAIN Salatiga, 7, 2, 2013, h. 474

17Imam Zaini, "Pembelajaran Seni Untuk Pemberdayaan Anak Jalanan di Sanggar Alang-alang", Surabaya, 2008, h. 4..

${ }^{18}$ B. Suyanto, "Anak jalanan di Kota Surabaya: Isu Prioritas dan Program", Laporan Penelitian, (Departemen Sosial Surabaya, 2003), h. 76. 
maupun orang lain. Banyak perilaku menyimpang dilakukan anak jalanan seperti ngelem (menghisap semacam lem jenis aica-aibon, uhu, aceton, thinner, ether, spirtus), sex bebas, tawuran, dan lain sebagainya. ${ }^{19}$

Anak jalanan juga sering berfikir bahwa dirinya orang yang bodoh, cenderung mengatasi masalah dengan jalan seenaknya (Pramunchtia \& Pandjaitan, 2010). Pendapat senada diungkapkan oleh Shofiah (2010: 70), yang menyebutkan bahwa pada anak jalanan memiliki cara pandang keliru. Sebagian besar anak jalanan merasa tidak setuju apabila mereka harus bergegas melaksanakan ibadah, meskipun adzan sudah terdengar. Hasil penelitian kepada 20 responden anak jalanan menunjukkan bahwa $50 \%$ merasa tidak setuju melaksanakan ibadah shalat secara rutin dan tepat waktu. Ketidaksetujuan lain juga ditunjukkan dalam hal bersikap sopan dan ramah kepada orang lain. Sebanyak $70 \%$ anak jalanan menganggap bahwa keramahan dan sopan tidak akan mendatangkan hasil rejeki yang banyak. Justru dengan keramahan mereka menganggap orang semakin tidak memberinya keuntungan. Berdasarkan studi pendahuluan yang dilakukan kepada 11 anak jalanan di kota Semarang, ditemukan $72.72 \%$ anak jalanan tidak memahami ajaran agamanya, 81,81\% enggan melaksanakan ibadah, 63,63\% suka berkelahi, 91\% merasa mendapatkan hinaan dan cemoohan dari masyarakat. Problem yang dialami anak jalanan di kota Semarang nampaknya tidak jauh berbeda dengan kebanyakan kelompok anak jalanan di Indonesia, namun karena secara kuantitas, anak jalanan di kota Semarang menunjukkan pertumbuhan yang luar biasa cepatnya, maka perlu upaya pengkajian secara mendalam.

Anak jalanan di kota Semarang memiliki keunikan tersendiri dibandingkan dengan kota-kota lain di Indonesia seperti Surabaya, dan Medan. Anak Jalanan di Semarang cenderung memiliki kekuataan pada basis kelompok (Wawancara dengan Widido, 2 Januari 2015). Pada beberapa kelompok anak jalanan terasa sangat solit, sehingga bentuk perilaku yang divisualisasikan mencerminkan identitas kelompoknya. Selain itu kelompok anak jalanan di Kota Semarang secara struktural mendapatkan binaan langsung dari Kementerian Sosial yang dilakukan oleh beberapa

19J. Danandjaja, Antropologi Psikologi: Teori, Metode, dan Sejarah Perkembangannya, (Jakarta: Rajawali Press, 1988), h. 43; Suyanto, ibid, h. 78; Zani, “Pembelajaran Seni Untuk Pemberdayaan Anak Jalanan di Sanggar Alang-alang" ", h. 6. 
yayasan di sekitar Semarang dan dimonitoring secara berkala oleh Dinas Sosial Provinsi Jawa tengah. ${ }^{20}$ Pembinaan yang dilakukan bersifat intensif dan terstruktur sesuai dengan program penanganan dan pemenuhan hak anak melalui program Kota Layak Anak (KLA). ${ }^{21}$ Meskipun demikian peran yang dilakukan oleh Kementerian Sosial melalui yayasan pembinaan anak jalanan dirasa belum optimal. Hal ini masih dapat dilihat dari semakin meningkatnya jumlah anak jalanan di kota Semarang. Meskipun telah memiliki layanan bimbingan dan pembinaan, masih saja terjadi penyimpangan nilai moral, dan sosial dalam kehidupan anak jalanan seperti telah dijelaskan di atas. Studi ini tentu menjunjukkan bahwa anak jalanan memiliki problem kesadaran beragama.

Problem keadaran beragama dipengaruhi berbagai faktor. Faktor yang diduga dapat mempengaruhi kesadaran beragama seseorang bersifat internal dan eksternal. Faktor internal adalah faktor yang berasal dari dalam diri individu seperti kepribadian, dan motivasi. Motivasi menjadi aspek penting dalam menentukan perilaku. Motivasi dapat diartikan sebagai faktor yang mengarahkan perilaku dalam bentuk usaha keras atau lemah. ${ }^{22}$ Chaplin (2001) menyebutkan bahwa motivasi merupakan aspek yang digunakan untuk menerangkan faktor yang ada dalam diri individu, dapat membangkitkan, mempertahankan, dan menyalurkan tingkah laku ke arah tujuan tertentu. ${ }^{23}$ Motivasi berhubungan erat dengan kekuatan yang berada di dalam diri manusia. ${ }^{24}$ Hasibuan (2000) menyebutkan bahwa motivasi mempersoalkan cara mengarahkan potensi, daya, dan kerjasama dalam mencapai tujuan tertentu. ${ }^{25}$

Faktor motivasional merupakan pendorong semangat yang sifatnya intrinsik dan ekstrinsik. Faktor bersifat intrinsik berarti faktor pendorong

${ }^{20}$ Era Atmiasih, Pemenuhan dan Perlindungan Hak Anak melalui Program Kota Layak Anak, Makalah, Seminar Advokasi Perlindungan Hak Anak diselenggarakan oleh (BP3AKB Provinsi Jawa Tengah, 2014), h. 9.

${ }^{21} \mathrm{Ibid}, \mathrm{h} .10$.

${ }^{22}$ Marihot Hariandja, Tua Efendi, Menejemen Suber Daya Manusia, Jakarta: Grasindo, 2002), h. 320.

23 J. P. Caplin, Kamus Lengkap Psikologi, (Jakarta: Rajawali Press, 2001), h. 312.

${ }^{24}$ Rafy Sapuri, Psikologi Islam: Tuntunan Jiwa Manusia Modern, (Jakarta: Rajawali Press, 2008), h. 218. h. 140 .

25Malayu S.P Hasibuan, Menejemen Sumber Daya Manusia, (Jakarta: Bumi Aksara, 2000), 
yang bersumber dari dalam diri sendiri, sedangkan faktor bersifat ekstrinsik erat kaitannya dengan faktor pemelihara yang bersumber dari luar diri individu, tetapi turut menentukan perilaku seseorang dalam kehidupannya (Herzberg, 2009). Lebih lanjut dijelasakan bahwa motivasi intrinsik berupa keberhasilan, kesempatan, kemajuan, peningkatan, keterlibatan, prestasi, ketaatan, kepatuhan, dan pengakuan. Motivasi ekstrinsik adalah status sosial, rasa aman, hubungan seseorang dengan kelompoknya, rekan, atasan, kebijakan, kondisi lingkungan, serta penghargaan atau sistem imbalan yang diperoleh. Individu dengan motivasi tinggi, akan selalu mengarahkan dirinya untuk meningkatkan kualitas kehiduan secara lebih baik, mengarahkan potensi yang dimiliki secara benar, dan mencapai kebahagiaan hidup. Tujuan penting dari motivasi adalah mengarahkan perhatian seseorang, mengatur upaya, meningkatkan potensi dan ketekunan, serta mendukung pengembangan strategi pencapaian tujuan atau rencana tindakannya secara positif dan terarah. Salah satu jenis motivasi yang saat ini memiliki kontribusi positif bagi kehidupan manusia adalah motivasi spiritual. Motivasi spiritual adalah dorongan untuk taat, tunduk, patuh, atas ketentuan kaidah nilai, moral, serta ketentuan ajaran agama. ${ }^{26}$ Motivasi spiritual merupakan dorongan akhlukkan ilham takwa, menghadirkan amar ma'ruf nahi munkar, lahir dari hasil renungan religious dan pengalaman batiniah. ${ }^{27}$ Motivasi spiritual dalam struktur kepribadian seseorang merupakan kebutuhan yang harus dicapai oleh setiap orang beragama, dan menjadi faktor internal penentu bagi pemenuhan kebutuhan hidup manusia, berfungsi sebagai penyeimbang (equilibrium). ${ }^{28}$ Faktor penentu lain selain faktor internal adalah faktor eksternal.

Faktor eksternal adalah faktor yang berasal dari luar diri individu seperti lingkungan sosial (masyarakat, pendidikan, dll). Faktor bersifat eksternal dapat diwujudkan dengan cara memberikan dukungan kepada individu dalam kelompok tertentu. Dukungan sosial adalah salah satu bentuk perhatian dari lingkungan sosial. Sarason et.al., menyebutkan bahwa

${ }^{26}$ Hasyim Hasanah, "Menejemen Bimbingan Agama Islam dalam Meningkatkan Adversity Quotient dan Motivasi Spiritual Penderita Vitiligo", Laporan Penelitian Individual, Fakultas Dakwah dan Komunikasi, IAIN Walisongo Semarang, 2012, h. 63.

27R.B Cairns \& Neckerman, “Social Network and Aggressive Behavior: Peer Support or Peer Rejection," Developmental Psychology Journal, 24, 6, 1988,h. 817.

28 Rafy Sapury, Psikologi Islam: Tuntunan Jiwa Manusia Modern, h. 221 
dukungan sosial adalah kondisi yang diliputi dengan informasi atau tindakan menyebabkan individu merasa diperhatikan, mendapatkan pertolongan pada saat membutuhkan. ${ }^{29}$ Sedangkan menurut Kuntjoro mengartikan dukungan sosial sebagai informasi verbal dan non verbal, bantuan riil, tingkah laku yang diberikan kelompok sosial tertentu, dan kehadiran yang memberikan keuntungan emosional, sehingga mempengaruhi perilaku individu tertentu. ${ }^{30}$

Individu dengan dukungan sosial tertentu cenderung merasa aman, nyaman, terlindungi, lega, damai karena merasa diperhatikan, dan disenangi. Adanya dukungan sosial yang positif menjadikan anak (khususnya anak jalanan) lebih mendapatkan pemenuhan hak-hak sosialnya, sehingga dapat meminimalisir penyimpangan perilaku. Dukungan sosial yang diberikan secara tepat dapat dijadikan sebagai salah satu energi positif seseorang dalam meningkatkan potensi internalnya salah satunya dalam hal beragama. Sebaliknya individu tanpa dukungan sosial cenderung merasa dirinya tidak berharga, cenderung anarkis, dan mengenggap dirinya sebagai orang tidak berguna. Hal ini diduga menjadi salah satu faktor penyebab orang lebih suka dan terpaksa tinggal di jalan, demi mendapatkan perhatian dan dukungan dari kelompoknya. Pada diri anak, kebutuhan mendapatkan perhatian dan dukungan dari sebayanya merupakan kebutuhan dasar dan utama dalam rangka mencapai tugas perkembangan sosial kemasyarakatan. ${ }^{31}$

Mendasarkan hal tersebut, maka perlu diupayakan langkah tepat agar anak-anak dapat memperoleh perkembangan kepribadian tepat, dan mengarahkan seluruh potesi yang dimiliki (baik material maupun spiritualnya) secara tepat pula. Salah satunya dengan meningkatkan kualitas kesadaran terhadap agamanya. Kesadaran beragama yang tepat dan diberikan kepada anak sedini mungkin, karena dapat mengarahkan seseorang merancang tujuan hidup yang lebih selaras dan realistis. ${ }^{32}$

\footnotetext{
29Sarason, I.G, Sarason BR, \& Pierce Gr, Relationship-Spesific Social Support: To ward A Model for the Analysis of Ssupportive Interactions, (California: Sage Publication., 1994), h. 88.

30Zs Kuntjoro, 2010, "Dukungan Sosial", Jurnal Psikologi, dalam http://www.epsikologi.com/usia/160802.html. diakses 11 Januari 2015

${ }^{31}$ Elizabet B Hurlock, Psikologi Perkembangan: Suatu Pendekatan Sepanjang Rentang Kehidupan, (Jakarta: Erlangga, 1991), h. 79

${ }^{32}$ F. Calhoun \& Acocella, J.R, Psikologi tentang Penyesuaian Hubungan Kemanusiaan, (Semarang: IKIP Press., 1990), h. 313
} 
Hasanah (2013) menyebutkan bahwa kesadaran beragama anak jalanan perlu dipahami dan dikembangkan, karena dengan adanya kesadaran mengenai agama secara tepat, memungkinkan seorang anak menemukan sistem nilai positif, selanjutnya dapat mengarahkan perkembangannya pada tema-tema pembangunan dan efisiensi kepribadian. Ini penting dilakukan karena anak jalanan seperti amanah Undang-undang Dasar (UUD) 1945, harus mendapatkan hak-haknya. ${ }^{33}$ Pemenuhan hak tersebut dilakukan melalui pembinaan dan pengembangan seluruh potensi dirinya, baik secara internal maupun eksternal, material maupun spriritual.

\section{B. Pembahasan}

Penelitian mengenai kontribusi positif antara motivasi spiritual dengan kesadaran adalah penelitian yang dilakukan oleh Syahri (2010), yang menyatakan bahwa motivasi spiritual berpengaruh signifikan dan positif dalam meningkatkan kepatuhan pajak. Penelitian ini memberikan kontribusi positif bahwa aspek motivasi spiritual yang tinggi dapat meningkatkan semua kepatuhan dalam diri seseorang. ${ }^{34}$ Seseorang dengan motivasi tinggi, mengarahkan dirinya secara positif untuk mentaati seluruh norma-norma yang diyakini benar, seperti kepatuhan dalam hukum, ekonomi, nilai moral, sosial, dan norma ajaran agamanya. Motivasi spiritual tinggi menjadi modal dasar pada perwujudan tujuan hidup. Hasanah (2013) dalam penelitiannya menyebutkan bahwa motivasi spiritual yang positif dapat dimanfaatkan untuk mengarahkan diri manusia mencapai kebahagiaan hidup, hal ini dikarenakan dengan adanya motivasi spiritual yang tinggi, seseorang selalu mengarahkan segala perilakunya sesuai dengan ajaran agamanya, melaksanakan dengan konsisten semua aturan agamanya, dan menghadirkan perilaku positif lain, dalam kaitannya mendapatkan kebahagiaan hidup di dunia dan akhirat. ${ }^{35}$

${ }^{33}$ Hasyim Hasanah, "Peran...", Ibid, h. 477.

${ }^{34}$ Ahmad Syahri, "Pengaruh Motivasi dan Tingkat Pendidikan terhadap Tingkat Kepatuhan Pajak", Skripsi, UIN Syarif Hidayatullah, 2010, dalam http://repository. uinjkt.ac.id/dspace/bitstream/123456789/23938/1/AHMAD SYAHRI (105082002603), diakses 11 Januari 2015.

35 Hasanah, Hasyim, “Peran...", Ibid, h. 478. 
Penelitian lain yang sejalan dengan hasil penelitian ini adalah penelitian yang dilakukan oleh Kasun yang menyatakan bahwa motivasi beragama berfungsi sebagai master motive, sehingga apa yang diterimanya menjadi satu kekuatan dalam kehidupannya. ${ }^{36}$ Motivasi adalah alat yang dapat dimanfaatkan untuk kepentingan pribadi untuk saling menghormati, menghargai, dan bersikap toleran. Al-Ghazali menyebutkan bahwa diri yang selalu mengarahkan dirinya secara positif, dan menjalankan ajaran agamanya secara konsisten, memunculkan semangat melahirkan hikmah kebijaksanaan, kekuatan mengendalikan amarah, melahirkan keadilan, dan membawa manfaat untuk orang lain. ${ }^{37}$ Penafsiran ini dikuatkan oleh Nicholson yang menyataan bahwa motivasi beragama memunculkan watak insan kamil yang merupakan unsur utama kepribadian seorang Muslim. ${ }^{38}$ Motivasi spiritual mengarahkan seseorang berperilaku ramah, rendah hati, tidak tergila-gila pada dunia, ikhlas, pemaaf, penyayang, dan selalu menghargai, menghormati orang lain.

Dari penelitian ini dapat dirumuskan bahwa motivasi spiritual dalam diri individu dapat mengarahkan dirinya menjadi orang yang menyadari sepenuhnya tugas-tugas perkembangannya salah satunya dalam rangka meningkatkan kesadaran beragama. Jika ditinjau dari ilmu psikologi, motivasi spiritual merupakan salan satu bentuk dorongan bersifat personal untuk mengerti dan memahami gejala-gejala psikis yang menjadi objek ilmu kejiwaan, sebagai refleksi pengalaman batiniahnya. Motivasi memiliki peran penting yang melatar belakangi tingkah laku seseorang. ${ }^{39}$ Ramayulis (2004: 40) menyebutkan bahwa motivasi dalam kehidupan seseorang memiliki peran sebagai daya pendorong melakukan sesuatu, penentu arah dan tujuan, penyeleksi perbuatan, dan penguji sikap perbuatan manusia sesuai nilai-nilai yang diyakini benar. 40

36Umi Laika Kasun, Pengaruh Motivasi Beragama Terhadap Sikap Toleran, Skipsi, (STAIN Salatiga, 2011), h. 45

${ }^{37}$ Al-Ghazali, Mengobati Penyakit Hati, (terj.) Ach. Sunarto, (Jakarta: Pustaka Amani, 1989), h. 20-21.

${ }^{38}$ Nichplson, 2002, h. 102-103, dalam http://www.e-psikologi.com/usia/ 160802.html. diakses 11 Januari 2015.

39 Bambang Syamsul Arifin, Psikologi Agama, (Bandung: Pustaka Setia, 2008), h. 132-133

40 Ramayulis, Psikologi Agama, (Jakarta: Kalam Mulia, 2002), h. 40. 
Motivasi dalam konteks Islam diperoleh dari kebutuhan tertinggi seorang manusia. Tata nilai tertinggi umat Islam adalah pada aspek aktualisasi ibadah. ${ }^{41}$ Motivasi yang tinggi selalu mengarahkan manusia untuk lebih tekun beribadah, terdapat sistem nilai yang diyakini sebagai kebutuhan bahwa beribadah adalah kebutuhan tertinggi, sehingga sikap dan perilakunya dapat diarahkan secara positif untuk mewujudkan kebahagiaan hidup yang hakiki. Kondisi inilah selanjutnya yang akan mempengaruhi pembentukan kesadaran seorang Muslim dalam menjalankan secara konsisten ajaran agamanya. ${ }^{42}$ Pandangan ini dikuatkan oleh hasil penelitian Hasanah (2013) menyebutkan bahwa motivasi yang tumbuh dalam diri seseorang menjadi salah satu kunci untuk mengembangkan kualitas kehidupan. Orang yang berkualitas adalah yang memiliki kesadaran. ${ }^{43}$ Kesadaran yang berada dalam aspek ruhaniah menjadikan dirinya sadar dengan keberadaan dan eksistensinya sebagai hamba Allah dan khalifah $f i$ al ardh.44 Sebagai hamba Allah, manusia melaksanakan penghambaan, menjadi khalifah fi al ardh berarti menjadi pengganti tugas kerasulan. Individu dengan kesadaran beragama tinggi biasanya diawali dengan memunculkan motivasi spiritual yang tinggi pula. Penafsiran ini dapat mengarahkan individu memiliki sistem nilai dan cara pandang positif, serta selalu menghadirkan perilaku konsisten dalam kehidupannya. ${ }^{45}$

Selain motivasi, faktor lain yang memiliki kontribusi positif dalam meningkatkan kesadaran beragama adalah dukungan sosial. Hasil penelitian menunjukkan bahwa dukungan sosial memiliki pengaruh positif dan signifikan dalam meningatkan kesadaran beragama. Penelitian ini sejalan dengan pendapat Dirdagunarsa (1989) yang menyatakan bahwa dukungan sosial bagi seorang anak dapat memberikan pemahaman dan mengenal kelebihan dan kekurangan yang ada pada dirinya, memperoleh informasi

${ }^{41}$ Sukanto, Nafsiologi Suatu Pendekatan Alternatif atas Psikologi, (Jakarta: Integritas Press, 2008), h. 32.

${ }^{42}$ Rafy Sapuri, Psikologi..., Ibid, h. 224.

${ }^{43}$ Hasyim, Menejemen Bimbingan Agama Islam dalam Meningkatkan Adversity Quotient dan Motivasi Spiritual Penderita Vitiligo, Laporan Penelitian Individual, Fakultas Dakwah dan Komunikasi (IAIN Walisongo Semarang, 2012), h. 77.

${ }^{44}$ Hasyim Hasanah, Pengaruh...,Ibid, h. 33.

45Teo Huijbers, Manusia Merenungkan Dirinya Sendiri, (Yogyakarta: Kanisius, 2000), h. 128; Amin dkk., Ibid, h. 35. 
penting dan tepat agar mencapai perkembangan diri serta kepribadian yang kuat. ${ }^{46}$ Dukungan sosial memberikan pemahaman bahwa apakah seseorang mendapatkan perhatian untuk menjalankan peran sosialnya secara tepat, menghargai orang lain, membina hubungan baik dengan sesame, dan bertanggung jawab dengan keputusannya. Pandangan sama disampaikan oleh Cairns dan Neckerman ${ }^{47}$ yang menyebutkan bahwa dukungan sosial merupakan sumber referensi bagi seseorang untuk mentaati kaidah aturan moral yang berlaku di lingkungan sosialnya. Ini menunjukkan bahwa dukungan sosial mengarahkan individu mengenali sistem nilai, memiliki cara pandang positif, dan memiliki konsistensi perilaku. Kondisi ini selanjutnya membentuk kesadaran. Kesadaran dengan dukungan sosial diarahkan pada tema ketaatan dan kepatuhan dalam menjalankan ajaran agamanya, serta mematuhi tata aturan nilai yang berlaku di lingkungan masyarakat.

Anyanya motivasi dan dukungan sosial yang diberikan secara bersama-sama dapat memberikan kontribusi besar dalam meningkatkan kesadaran beragama. Kondisi ini sejalan dengan penelitian yang dilakukan oleh Rahmi (2011) bahwa dukungan sosial dan motivasi berpengaruh secara signifikan terhadap prestasi. Orang tua yang memberikan dukungan sosial secara positif, dan motivasi kepada anak-anaknya, memiliki peran dalam meningkatkan prestasi. ${ }^{48}$ Penafsiran yang dapat diberikan dari hasil penelitian Rahmi adalah, seseorang melalui motivasi dan dukungan sosial positif, secara positif meningkatkan tingkat kesadaran beragama yang ada dalam dirinya. Motivasi merupakan faktor yang bersifat internal, sedangkan dukungan sosial merupakan faktor yang bersifat eksternal.

Interaksi antara faktor internal dan eksternal yang positif di dalam diri individu secara psikologi memunculkan dinamika psikologis berupa rasa kepercayaan yang tinggi serta kesadaran atas penciptaannya. Selanjutnya kondisi ini membantu individu mengerti, memahami, dan menghayati arti kehidupan. Maslow (1970) menggambarkan manusia yang sudah mengaktualisasikan seluruh pengalaman kehidupannya sebagai orang yang telah

46YS Dirdagunarsa, “Mengenal Masa Remaja”, Jurnal Anima, 02, 11, 1989, h.10-21.

${ }^{47}$ Cairns, R. B, \& Neckerman, "Social Network and Aggressive Behavior: Peer Support or Peer Rejection", Developmental Psychology Journal, 24, 6, 1988, 815-832

${ }^{48}$ Rahmi, ibid, h. $4 .$. 
memenuhi kebutuhan, melakukan apapun yang bias dilakukan, dan selalu mendapatkan dukungan dari orang lain di sekelilingnya. Mereka mendapatkan rasa aman, pengakuan, dan kebutuhan apapun dari diri dan lingkungan sosialnya. Mengaktualisasikan diri dalam pandangan Maslow seperti dikutip Jervis, ${ }^{49}$ berarti adanya kemampuan mencapai pengalaman puncak (peak experience), kondisi ini merupakan perwujudan dimana individu merasakan bahwa dirinya mamiliki kesadaran penuh. Kesadaran bahwa dunia ini tampak dan individu itu merasa selaras dengan dirinya. Pandangan sama dikemukakan oleh Watson yang menyebutkan bahwa pengalaman tertinggi dari wujud ruhaniah adalah bagaimana seseorang memiliki kemampuan untuk mengintegrasikan seluruh faktor yang bersifat internal dan eksternal dalam kehidupannya. ${ }^{50}$

Faktor internal muncul sebagai dorongan atau pendorong dari sikap dan cara pandang atas sistem nilai yang diyakini benar, sedangkan faktor eksternal lebih mengarah pada komponen di luar diri yang secara positif memberikan live support pada manusia untuk dapat meningkatkan kualitas kehidupannya. Motivasi spiritual sebagai faktor internal, dengan didukung adanya dukungan sosial sebagai faktor eksternal, mengarahkan individu mendapatkan keuntungan secara optimal dalam mengemban tugas perkembangannya (sebagai abdullah dan khalifah). ${ }^{51}$ Lebih lanjut Sobur menjelaskan bahwa keberadaan motivasi merupakan personalitas, sedangkan dukungan sosial adalah wujud kontestasi sosial untuk dapat diterima dan mendapatkan penghargaan dari lingkungan sosialnya. Safarino menyebutkan bahwa dukungan sosial menjadi salah satu bentuk penerimaan, penghargaan, serta elemen dasar derajat kepuasan hidup. 52 Motivasi spiritual dan dukungan sosial menjadikan individu menjadi lebih tenang, memiliki dan memunculkan keyakinan, dan kesempatan melakukan perbuatan yang disenangi dan sesuai dengan nilai norma yang ada, serta mampu mengambil peran baru yang belum pernah

\footnotetext{
${ }^{49}$ Matt Jervis, Teori-teori Psikologi: Pendekatan Modern untuk Memahami perilaku, Perasaan, \& Pikiran Manusia, (terj.), (London: Routledge, 2010), h. 96.

${ }^{50}$ D Watson, Effect..., Ibid, h. 1019.

${ }^{51}$ Alex Sobur, Psikologi Umum, (Bandung: Pustaka Setia, 2003), h. 286.

52Edward P Safarino, Health Psychology Biopshychososial Interaction, (USA: John Willey \& Sons., 1994), h. 39; M.R Dimetteo, Social Support and Patient Adherence to Medical Threatment: a Meta Analysis, Health Pshychology Journal, 23, 2, 2004, h. 211.
} 
dilakukannya. ${ }^{53}$ Sementara itu House, dkk., seperti dikutip oleh Safarino (1994) menyebutkan bahwa dukungan sosial merupakan faktor eksternal berupa bantuan emosional, instrumental, informasi, dan adanya jaringan sosial. ${ }^{54}$ Dengan adanya dukungan sosial, maka seseorang menjadi lebih empatik, mudah menjalin pertukaran sosial, memiliki kemampuan membimbing, mengontrol dirinya secara positif, dan hubungan interpersonal yang memuaskan.

Dukungan sosial memiliki beberapa komponen yang sangat dibutuhkan indivudu, yaitu komponen moral. Komponen moral berkaitan dengan guidance atau bimbingan dari lingkungan sosialnya. Komponen ini berbentuk nasehat, saran, dan informasi yang diperlukan dalam memenui kebutuhan hidupnya, menghadapi masalah, dan mengembangkan potensinya. Dukungan sosial secara psikologis merupakan wadah dan sumber kekuatan, kepercayaan, dan ketahanan seseorang. Bentuk-bentu dari kukungan sosial ini tentu memainkan peran penting sebagai salah satu faktor dalam meningkatkan kesadaran.

Motivasi spiritual yang tinggi, disertai dukungan sosial yang penuh mengarahkan individu mencapai kondisi tangguh dan kuat. Hilman menyebutkan bahwa motivasi dan dukungan sosial secara bersama-sama memberikan keuntunngan untuk merubah energi negatif menjadi positif, merubah ke arah lebih baik, karena menyediakan tempat bagi individu memunculkan kesadaran dalam dirinya. ${ }^{55}$ Manan menyebtkan bahwa dukungan sosial dan motivasi akan menjadikan seseorang berada dalam kondisi dimana potensi, keberadaan, dan kemampuannya diakui. ${ }^{56}$ Ini dapat dipahami bahwa motivasi dengan dukungan sosial yang baik secara positif pada akhirnya dapat dijadikan sarana meningkatkan kesadaran beragama pada diri individu, dalam setiap aspeknya yaitu sistem nilai, sikap dan cara pandang positif, serta konsistensi perilaku.

53I Tarakanita, "Hubungan Status Identitas Etnik dengan Konsep Diri Mahasiswa", Jurnal Psikologi, 07, 01. 2001, h. 10

${ }^{54}$ Edward P Safarino, Ibid, h. 54.

55Hilman, "Kemandirian Remaja yang Tinggal di Panti Asuhan ditinjau dari Persepsi Pelayanan Sosial dan Dukungan Sosial," Tesis, (tidak dipublikasikan), UGM Yogyakarta, 2002, h. 74 .

56Manan, "Interaksi Sosial Pelajar dengan Krlompok Teman Sebaya", Majalah Ilmu Sosial, 20, 3, 1993, h. 321. 


\section{Kesimpulan}

Berdasarkan hasil penelitian dapat ditarik kesimpulan bahwa motivasi dan dukungan sosial dapat meningkatkan kesadaran beragama anak jalanan diterima. Hubungan integratif signifikatif ini menjadikan anak jalanan lebih mampu menemukan strategi yang efektif dan efisien dalam rangka meningkatkan kualitas kesadara beragamanya. Hal lain yang dapat dijelaskan dalam penelitian ini adalah hasil uji signifikasi yang tinggi pada pengaruh masing-masing variabel menunjukkan bahwa untuk meningkatkan kesadaran beragama pada anak jalanan, maka upaya motivasi dan adanya dukungan harus mendapatkan perhatian lebih pada penelitian selanjutnya. Untuk mendapatkan bentuk upaya lain dalam meningkatkan kesadaran diri, maka peneliti selanjutnya dapat mempertimbangkan pengkajian lebih rinci, dengan mendasarkan pada setiap aspek variabel penelitian, sehingga pembahasannya lebih komprehensif dan mendalam

\section{Daftar Pustaka}

Allport, Gordon W. Pattern and Growth in Personality, London: Holt Rinehart \& Winston, 1991.

Amin, Munirul, dkk, Psikologi Kesempumaan, Yogyakarta: Ar Ruz, 2005.

Arifin, Bambang Syamsul, Psikologi Agama, Bandung: Pustaka Setia, 2008.

Atmiasih, Era, "Pemenuhan dan Perlindungan Hak Anak melalui Program Kota Layak Anak", Makalah, Seminar Advokasi Perlindungan Hak Anak diselenggarakan oleh BP3AKB Provinsi Jawa Tengah, 2014.

Azwar, Saifudin, Reliabilitas dan Validitas, Yogyakarta: Pustaka Pelajar, 2001.

Azwar, Faifudin, Metode penelitian, Yogyakarta: Pustaka Pelajar, 2007.

Calhoun F \& Acocella, J. R, Psikologi tentang Penyesuaian Hubungan Kemanusiaan, Semarang: IKIP Press, 1990.

Cairns, R. B, \& Neckerman, "Social Network and Aggressive Behavior: Peer Support or Peer Rejection", Developmental Psychology Joumal, 24, 6, 1988, 815832

Caplin, J. P. , Kamus Lengkap Psikologi, Jakarta: Rajawali Press, 2001. 
Dahlan, dkk. , Kamus Ilmiah Populer, Surabaya: Arkola, t.th.

Danandjaja, J. , Antropologi Psikologi: Teori, Metode, dan sejarah perkembangannya, Jakarta: Rajawali Press, 1988.

Departemen Sosial, Pedoman Penyelenggaraan Pembinaan Anak Jalanan, Surabaya, 2000.

Dianah, A, "Dukungan Sosial dan Konsep Diri Pekerja Anak", Skripsi, Institut Pertanian Bogor, 2011.

Dimetteo, M. R, "Social Support and Patient Adherence to Medical Threatment: a Meta Analysis", Health Pshychology Joumal, 23, 2, 2004, 207-218.

Dirdagunarsa, YS., "Mengenal Masa Remaja", Jumal Anima, 02, 11, 1989, 10-21

Gea, Antonius Atosakhi, 2002, Relasasi dengan Diri Sendiri, Jakarta: Elexmedia Komputindo

Al-Ghazali, Mengobati Penyakit Hati, (terj.) Ach. Sunarto, Jakarta: Pustaka Amani, 1989.

Hariandja, Marihot Tua Efendi, Menejemen Suber Daya Manusia, Jakarta: Grasindo, 2002.

Hasanah, Hasyim, "Pengaruh Kesadaran dan Kematangan Beragama terhadap Komitmen Organisasi Karyawan: Studi Kasus di RSUD Tugurejo Semarang", Tesis (tidak dipublikasikan), IAIN Walisongo Semarang, 2008.

Hasanah, Hasyim, "Menejemen Bimbingan Agama Islam dalam Meningkatkan Adversity Quotient dan Motivasi Spiritual Penderita Vitiligo," Laporan Penelitian Individual, Fakultas Dakwah dan Komunikasi, IAIN Walisongo Semarang, 2012.

Hasanah, Hasyim, "Peran Strategis Aktivis Nurul Jannah al Firdaus dalam Membentuk Kesadaran Beragama Perempuan Miskin Kota", Inferensi Jumal Penelitian Sosial Keagamaan STAIN Salatiga, 7, 2, 2013, 473-494.

Hasibuan, Malayu S. P, Menejemen Sumber Daya Manusia, Jakarta: Bumi Aksara, 2000.

Hezberg, Frederick "Frederick Hezberg's Motivation and Hygien Factors", , 2009, dalam http://busunessballs. com/Hezberg. html, diakses 12 Januari 2015 .

Hilman, "Kemandirian Remaja yang Tinggal di Panti Asuhan ditinjau dari Persepsi Pelayanan Sosial dan Dukungan Sosial", Tesis, (tidak dipublikasikan), UGM Yogyakarta, 2002. 
Huijbers, Teo, Manusia Merenungkan Dirinya Sendiri, Yogyakarta: Kanisius, 2000.

Hurlock, Elizabet B, Psikologi Perkembangan: Suatu Pendekatan Sepanjang Rentang Kehidupan, (Jakarta: Erlangga, 1991).

Hutami, Ginarsih, and Hartanto, Fitri and Hendrianingtyas, Meita, "Hubungan Perilaku Berisiko dengan Infeksi HIV AIDS pada Anak Jalanan di Semarang". Under Graduate Thesis, Faculty of Medicine Diponegoro University, 2014, dalam http://eprint. undip.ac.id/44649/2/ Gunarsih _hutami_22010110130169_bab 1KTI. pdf. html, diakses 11 Januari 2015.

Jalaluddin, Psikologi Agama: Memahami Perilaku Keagamaan dengan Mengaplikasikan prinsip-prinsip Psikologi, (Jakarta: Rajawali Press, 2007).

Jervis, Matt, 2010, Teori-teori Psikologi: Pendekatan Modern untuk Memahami perilaku, Perasaan, \& Pikiran Manusia, (terj. ), London: Routledge.

Kasun, Umi Laika, "Pengaruh Motivasi Beragama terhadap Sikap Toleran", Skipsi, (STAIN Salatiga, 2011)

Kuntjoro, Zs, "Dukungan Sosial", Jurnal Psikologi, 2010, dalam http://www.epsikologi.com/usia/160802. html. diakses 11 Januari 2015.

LPPM USM, "Studi Karakteristik Anak Jalanan dalam Upaya Penyusuan Program dan Penanggulangannya: Kajian Empirik di Kota Semarang", Riptek, Universitas Semarang, 2010.

Maharani, Reny, Retno Indrawati, \& Fery Effendy "Relationship Between Social Support With Self Concept of Street Children", dalam e-Journal Keperwatan, Universitas Airlangga, 4, 2, 2004, dalam http://airlangaa. ac. id, diakses 11 Januari 2015.

Manan, "Interaksi Sosial Pelajar dengan Krlompok Teman Sebaya", Majalah Ilmu Sosial, 20, 3, 1993, h. 317-332.

Nashori, Fuad, "Kompetensi Interpersonal ditinjau dari Kematangan Beragama, dan Jenis Kelamin", Tesis, (tidak dipublikasikan), UGM Yogyakarta, 2000.

Nurmawati, "Hubungan antara Dukungan Sosial dengan Harga Diri," Jurnal Psikologi, 26, 1, 2010, 19-17

Pramuchtia, Yunda \& Nurmala K. P, “Konsep diri Anak: Kasus Anak Jalanan di Kota Bogor Provinsi Jawa Barat", Jurnal Transdisiplin Sosiologi, Komunikasi, dan Ekologi Manusia, 04, 02, 2010, 255-272.

Ramayulis, Psikologi Agama, Jakarta: Kalam Mulia, 2002. 
Safarino, Edward P, Health Psychology Biopshychososial Interaction, USA: John Willey \& Sons, 1994.

Saituti, "Problematika Anak Jalanan Ibu Kota: Faktor-faktor Penyebabnya", Jumal Psikososiologi, 4, 2, 2001, 315-334.

Sapuri, Rafy, Psikologi Islam: Tuntunan Jiwa Manusia Modern, Jakarta: Rajawali Press, 2008.

Sarason, I. G, Sarason BR, \& Pierce Gr, Relationship-Spesific Social Support: To ward A Model for the Analysis of Ssupportive Interactions, California: Sage Publication, 1994.

Setiawan, Eka, "Hadapi Anak Jalanan Pemerintah Harus Tegas", 2014,, dalam http://sindonews. com, Anak jalanan. dok. Istimewabenradit. wordpress. com, diakses 11 Januari 2015.

Sobur, Alex, Psikologi Umum, Bandung: Pustaka Setia, 2003.

Soedarsono, Soemarno, Penyemaian Jati Diri, Jakarta: Elexmedia Komputindo, 2000.

Sukanto, Nafsiologi Suatu Pendekatan Alternatif atas Psikologi, Jakarta: Integritas Press, 2008.

Suyanto B., "Anak Jalanan di Kota Surabaya: Isu Prioritas dan Program", Laporan Penelitian, Departemen Sosial Surabaya, 2003.

Syahri, Ahmad, Pengaruh Motivasi dan Tingkat Pendidikan Terhadap Tingkat Kepatuhan Pajak, Skripsi, UIN Syarif Hidayatullah, 2010, lihat dalam http://www.http://repository.uinjkt.ac.id/dspace/bitstream/123456789/2 3938/1/AHMAD SYAHRI (105082002603), diakses 11 Januari 2015.

Tarakanita, I, "Hubungan Status Identitas Etnik dengan Konsep Diri Mahasiswa", Jumal Psikologi, 07, 01. 2001, 01-14.

Watson, D., Anxiety and Depression: Negative Affectivity in Children, USA: Departemen of Abnormal Psychology, 1991.

Watson, D, "Effect, Personality, and Social Activity", Joumal of Personality and Social Psychology, 63, 2, London: Rougtagul, 1992, pp. 1011-1025.

Zaini, Imam, "Pembelajaran Seni Untuk Pemberdayaan Anak Jalanan di Sanggar Alang-alang", Surabaya, 2008. 
